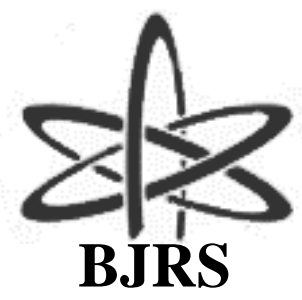

\author{
BRAZILIAN JOURNAL \\ OF \\ RADIATION SCIENCES \\ 09-01A (2021) 01-09
}

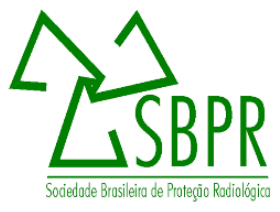

\title{
Shelf-life of papaya nectar submitted to ionizing radiation
}

Harder M. N. C. ${ }^{a, b, c}$, Andrade T. ${ }^{c}$, Reis F. M. ${ }^{c}$, Feitosa N. M. ${ }^{c}$, Pereira P. ${ }^{c}$, Roberto S. P. ${ }^{c}$, Neme-Oyan F. F. ${ }^{c}$, Harder L. N. C. ${ }^{\text {d }}$, Oliveira S.R. ${ }^{\text {b e }}$ and Arthur V. ${ }^{\text {b, f }}$

${ }^{a}$ Departamento de Engenharia Agronômica Faculdade de Tecnologia de Piracicaba - FATEP

Av. Rio Claro, 290 13414-048 Piracicaba, SP, Brazil

${ }^{b}$ Instituto de Pesquisas Energéticas e Nucleares (IPEN / CNEN - SP)

Av. Professor Lineu Prestes 224205508-000 São Paulo, SP, Brazil

${ }^{c}$ Faculdade de Tecnologia de Piracicaba-Fatec "Dep. Roque Trevisan"

Av. Diácono Jair de Oliveira, 65113414-155 Piracicaba, SP, Brazil

${ }^{d}$ Universisdade do Norte do Paraná (UENP)

${ }^{e}$ Instituto de Zootecnia - APTA

Estrada do Meio, 150013412-050 Piracicaba, SP, Brazil

${ }^{f}$ Departamento de Radiobiologia e Ambiente Centro de energia Nuclear na Agricultura (CENA/USP)

Av. Centenário, 303 13400-980 Piracicaba, SP, Brazil

marcia.harder@fatec.sp.gov.br

\begin{abstract}
A kind of drink consumption that has grown and appreciated for the most people is the nectar. The papaya nectar was recognized as a differentiated form of this fruit, with which the industry also gains in time of conservation, since the papaya is an extremely perishable fruit. The aim of this study was to evaluate gamma radiation as a way of conserving papaya nectar. The nectar was developed and subjected to gamma radiation at the dose of $1 \mathrm{kGy}$ in a dose tax of $0.356 \mathrm{kGy}$.hour-1 and compared this treatment with the control group (0 kGy). According to the results obtained, it can be concluded that the dose used was adequate for the conservation of this product for the period evaluated reaching the aim.
\end{abstract}

Keywords: nectar fruit, gamma radiation, Carica papaya. 


\section{INTRODUCTION}

Papaya (Carica papaya L.) is a tropical fruit of several sizes and shapes; with smooth and thin peel and yellow color; thick pulp, yellow, orange, red or purple in selected lines; with soft, exquisite, sweet flesh, very pleasant and digestive. Inside the fruit, there are many brown or black color, round, wrinkled seeds covered by a succulent outer layer, the sarcotest, followed by a hardinner layer, the sclerotest [1].

The production of papaya has been standing out among the different tropical fruits. The main producers are Brazil, Mexico, Nigeria, India and Indonesia. However, high production still faces problems such as deficiency in storage and transportation, especially in the post-harvest period, which promotes increased losses [2].

The papaya is a fragile nature fruit, being target of several post-harvest diseases, as well as the ease of suffering damage due to its thin bark. Furthermore, it is a fruit that does not withstand low temperatures, increasing the difficulties in its storage [3].

The fruit processing becomes an interesting option to minimize this situation, because elaborating pulps; juices and/or nectars applying conservation treatments and a suitable packaging, it increases the shelf life of the product, besides unifying the facilitate storage, distribution and consumption [2].

Some studies have shown an increase in the consumption of juices and nectars in recent years, due to factors such as practicality, nutritional value and health concern, there is still a shortage of papaya nectar in the market. However, due to the diversity of fruits in the country and cultural miscegenation, there is demand for diversified flavors [4].

Nectar is a sweet drink non-alcoholic and non-fermented base of fruit juice in which the concentration of the pulp is at least 20 to $30 \%$ depending on the fruit [5].

For MAPA (Ministry of Agriculture Livestock and Food Supply) nectars are considered nonfermented, non-alcoholic, consisting of juice or pulp, ranging from 25 to $50 \%$, added water, sugar and optionally acids, intended for direct consumption. According to the same governmental entity this kind of beverage is an unfermented, non-concentrated and undiluted drink (excepted specific cases) obtained from the ripe and healthy fruit or vegetable by an appropriate technological process 
of characteristic color, aroma and flavor submitted to treatment that ensures its preservation and presentation until the moment of consumption [6].

Papaya nectar is an unfermented beverage obtained from the dissolution in drinking water of the edible part of papaya (Carica papaya L.) and sugars, intended for direct consumption and may be added to acids. To be characterized as such, the beverage should meet the following minimum parameters: $35 \%$ juice or pulp, $10^{\circ}$ Brix solids soluble at $20^{\circ} \mathrm{C}, 6 \%$ total sugars and $0.10 \%$ acidity in citric acid [2].

The Brazilian law defined the papaya nectar as a product in the $18^{\text {th }}$ article of Decree No. 6,871, 2009, obtained from the edible part of the papaya (Carica papaya L.), by means of an appropriate technological process [7].

Irradiation is an excellent method of food conservation, as well as reinforces the action of other applied processes for the same purpose. Irradiation satisfies completely the objectives of giving food nutritional stability and sanitary conditions along shelf life $[8,9]$.

In a research, Harder et al. (2009) concluded that the irradiation did not induce significant alterations in the physicochemical and sensorial characteristics of kiwi nectar, with an exception on the total of ascorbic acid at doses of 1.0 and $2.0 \mathrm{kGy}$ [9].

The shelf life definition is derived from stability studies that provide evidence of how the quality of a product varies over time under the influence of various factors such as microbial contamination or physicochemical instability [10].

Because of this, the aim of this work was to evaluate the shelf life period of irradiated papaya nectar by changes in microbiologic and physicochemical quality attributes.

\section{MATERIALS AND METHODS}

\subsection{Nectar preparation}

The papaya used for the experiment was obtained in the local commerce of Piracicaba. 
The fruits were forwarded at Food Technology laboratory at Fatec Piracicaba and before the despoliation occurred the sanitization of the fruit then undergoing the process of cutting and removing the inedible parts and taken to the blender, where it was processed until homogeneous.

To preparing the papaya nectar, $1.572 \mathrm{~kg}$ of papaya pulp was used and mixed with water and $12 \%$ of sugar, adapted of Braga e Conti-Silva (2014) [11].

Then the nectar was bottled in sterilized glass bottles $(150 \mathrm{~mL})$ in boiling water and the vessel was subjected to steam exhaustion to keep the vessels hermetically sealed and subjected to vacuum.

\subsection{Nectar irradiation}

The papaya nectar samples were submitted to gamma radiation using the Gammacell 220 Excel irradiator, MDS, Nordion, by Cobalt 60 source, located at the Center for Nuclear Energy in Agriculture (CENA/USP). The doses 0 and $1 \mathrm{kGy}$ were used under a dose rate of $0.712 \mathrm{kGy} \cdot \mathrm{h}^{-1}$.

Dosimetry was performed using 5-mm-diameter alanine dosimeters (Bruker Instruments, Rheinstetten, Germany), and the free radical signal was measured with Bruker EMS 104 EPR Analyzer.

The actual dose was within 0.02 of the target dose. Samples were turned $360^{\circ}$ continuously during the irradiation process to achieve uniform target doses and the non-irradiated control was placed outside the irradiation chamber to have the same environmental temperature effect as that of their radiated sample.

The samples were analyzed at 2 different times: 0 and 120 days after irradiation with 60Co.

Both analyses were carried out according to normative instruction no. 37/2018 and RDC $12 / 2001[7,12]$.

\subsection{Counting of mold and yeast}

The counts of molds and yeasts were carried out using growing medium sabouraud agar and incubation at $21^{\circ} \mathrm{C}$ for 3 to 5 days [13].

\subsection{Determination of coliform group (MPN)}


The determination of the MPN (most probable number) was used in order to carry out the analyses to determine the presence of the coliform group in the samples. So it was used a fermentation method in multiple tubes. In the first series of 3 tubes of lactose broth $1 \mathrm{ml}$ of the 10-1 dilution was inoculated and in the second and third series $1 \mathrm{ml}$ of the dilutions 10-2 and 10-3, respectively.

The tubes were incubated at $35^{\circ} \mathrm{C}$ for 48 hours. Tubes with positive results should be inoculated in lactose broth - bright green-bile $2 \%$ and incubated at $35^{\circ} \mathrm{C}$ for 48 hours. The determination of the MPN of coliform bacteria was made from the number of positive tubes with the aid of the Hoskins Table [13].

\subsection{Physicochemical analysis}

Analyzes of $\mathrm{pH}$, total acidity and content of soluble solids were performed according to the methodology described in AOAC (1995) [14].

\section{RESULTS AND DISCUSSION}

Table 1 shows the results data obtained in the MPN analysis of the papaya nectar samples with increasing doses of gamma radiation (60Co). 
Table 1: Results of coliform bacteria (MPN) and total counting mold and yeast of papaya nectar sample

\begin{tabular}{lll}
\hline Dose $(\mathrm{kGy})$ & Coliform $(\mathrm{MPN})$ & Total mold and yeast $(\mathrm{CFU})$ \\
\hline Time 0 & & \\
\hline $0 \mathrm{kGy}($ Control) & $1.0 \times 10-1$ & Uncountable \\
\hline $1 \mathrm{kGy}$ & Analysis error & Uncountable \\
\hline Time 120 days & & \\
\hline $0 \mathrm{kGy}($ Control $)$ & Deteriorated sample & Deteriorated sample \\
\hline $1 \mathrm{kGy}$ & $<1.0 \times 10-1$ & 1 CFU \\
\hline
\end{tabular}

During the initial analysis of time 0 , probably should have occurred a contamination in the inoculation of the sample submitted to the treatment of gamma radiation promoting a false positive, which did not remain throughout the evaluation process, being the last sample in accordance with the microbiological standards established by RDC 12/2001 [12] at the last day, what did not occurred with the control group.

These results obtained presented higher values than the values obtained by Cubas and Torres (2019) [15], who found 10 CFUs in yellow dragon fruit nectar that were submitted to UV irradiation for increased shelf life. Gamma radiation showed high efficiency in this study.

Using gamma radiation to treat raspberries, Gimarães et al. (2013) [16] found that irradiation reduces weight loss and filamentous fungi and yeast count with doses of 1.0 and $2.0 \mathrm{kGy}$. This conclusion confirms the results of this research that found the control of these microorganisms with $1.0 \mathrm{kGy}$ dose.

Table 2 shows the average data obtained in the analysis of hydrogenionic potential $(\mathrm{pH})$; total acidity and content of soluble solids, in papaya nectar samples with increasing radiation doses.

By the results of the Table 2 we could observe that values practically did not differ between the control group and the sample irradiated. 
Table 2: Average values found for analyzes of $\mathrm{pH}$, total acidity, and tenor of soluble solids in papaya nectar irradiated samples

\begin{tabular}{llll}
\hline Dose $(\mathrm{kGy})$ & $\mathrm{pH}$ & $\begin{array}{l}\text { Total acidity }\left(\mathrm{g} .100 \mathrm{~g}^{-1}\right. \\
\text { expressed in citric acid) }\end{array}$ & $\begin{array}{l}\text { Soluble } \\
\left({ }^{\circ} \text { Brix }\right)\end{array}$ \\
\hline Time 0 & & & solids \\
\hline $0 \mathrm{kGy}($ Control) & 5.5 & 0.12 & 16.5 \\
\hline $1 \mathrm{kGy}$ & 4.11 & 0.15 & 14.1 \\
\hline Time 120 days & & & Deteriorated sample \\
\hline $0 \mathrm{kGy}($ Control) & Deteriorated sample & Deteriorated sample & 16.6 \\
\hline $1 \mathrm{kGy}$ & 4.05 & 0.14 & \\
\hline
\end{tabular}

The results obtained met the requirements described in Brazilian normative instruction 37/2018 [7], which presents a minimum values of 4.0 for $\mathrm{pH}$; 0.1 for Total acidity $\left(\mathrm{g} .100 \mathrm{~g}^{-1}\right.$ expressed in citric acid) and 9.0 for content of soluble solids.

But these values did not match with Cubas and Torres (2019) [15] that found values like 3.6 for $\mathrm{pH} ; 0.18 \mathrm{~g} .100 \mathrm{~g}^{-1}$ for total acidity and 13.0 for content of soluble solids, being a little discrepant with the values found in this research.

The results are also in disagree with Harder et al. (2009) [9], because they found values of 3.0 for $\mathrm{pH} ; 8.8 \mathrm{~g} .100 \mathrm{~g}^{-1}$ for total acidity and 16.7 for tenor of soluble solids of kiwi nectar irradiated.

Nevertheless, all values are in according with Brazilian normative instruction that regulate the norms and standards for this kind of product like nectars and juices.

\section{CONCLUSION}

By the results showed it could be concluded that the dose used was adequate for the conservation of this product for the period evaluated reaching the aim. 


\section{ACKNOWLEDGMENT}

We are grateful to CENA/USP for having irradiated the samples.

\section{REFERENCES}

[1] MANICA I. Fruticultura tropical: mamão. São Paulo: Agronômica Ceres, 1982.

[2] BRAFA H. F. Nécta de Mamão: uma Alternativa Tecnológica à Redução de Perdas PósColheita. 2019.

Available

at:

$<$ https://www.portaleducacao.com.br/conteudo/artigos/nutricao/nectar-de-mamao-umaalternativa-tecnologica-a-reducao-de-perdas-pos-colheita/59328>. Last accessed: 10 Jan. 2019.

[3] BRAGA H. F. Desenvolvimento de nectar à base de mamão (Carica papaya L.) adicionado de inulina e oligofrutos, Unesp, São José do Rio Preto, 2013.

[4] SANTOS A. B.; BOTTONI S. S.; SILVA D. A.; SÃO JOSÉ J. F. B.; SILVA E. M. M. Study of the consumers of ready-to-drink juices and fruit nectars. F Sci Techn, v. 38, p. 504-512, 2018.

[5] BRASIL. Regulamento técnico geral para fixação dos padrões de identidade e qualidade para polpa de fruta. Available at: <www2.agricultura.rs.gov.br/uploads/126989581629.03_enol_in_1_00_mapa.doc>. Last accesses: 16 Jan. 2019.

[6] BRASIL. Instrução normativa no. 37 de outrubro de 2018. Available at: <http://www.in.gov.br/materia/-/asset_publisher/Kujrw0TZC2Mb/content/id/44304943/do12018-10-08-instrucao-normativa-n-37-de-1-de-outubro-de-2018-44304612>. Last accesses: 16 Jan. 2019.

[7] BRASIL. Decreto 6.871 de 04 de junho de 2009. Available at: <http://www.planalto.gov.br/ccivil_03/_Ato2007-2010/2009/Decreto/D6871.htm (2019)>. Last accesses: 20 Jan. 2019. 
[8] EMBRARAD. Embrarad. Available at: <http://www.embrarad.com.br>. Last accesses: 02 Feb. 2019.

[9] HARDER M. N. C.; TOLEDO T. C. F.; FERREIRA A. C. P.; ARTHUR V. Determination of changes induced by gamma radiaiton in nectar of kiwi fruit (Actinidia deliciosa). Rad Phys Chem, v. 78, p. 579-582, 2009.

[10] ORIQUI L. R.; MORI M.; WONGTSCHOWSKI P.; FREITAS S. R.; SANTOS J. G. M. Definição de Shelf life para produtos químicos - a importância de um guia de estabilidade específico para o segmentos. Quím nova, v. 34, p. 1869-1874, 2011.

[11] BRAGA H. F.; CONTI-SILVA A. C. Determinação da doçura ideal em néctar de mamão adicionado de açúcar. Ciên Rural, v. 44, p. 723-727, 2014.

[12] BRASIL. Resolução RDC no. 12 de 02 de janeiro de 2001. Avalible at: <http://portal.anvisa.gov.br/documents/33880/2568070/RDC_12_2001.pdf/15ffddf6-37674527-bfac-740a0400829b>. Last accesses: 05 Feb. 2019.

[13] AMERICAN PUBLiC HEALTH ASSOCIATION. Compendium of methods for the microbiological examination of foods. $5^{\text {th }}$ Edition, Washington: Alfa Press, 2015.

[14] AOAC. Official methods of analysis of AOAC International. Washington: AOAC, 1995.

[15] CUBAS J. L. C.; TORRES D. R. Evaluación físico-química y microbiológica del néctar de pitahaya amarilla (Hylocereus triangularis), sometido a tratamientos por radiación con luz ultravioleta UV-C y pasteurización, Universidad Señor de Sipán Pimentel, Peru, 2019.

[16] GUIMARÃES I. C.; MENEZES E. G. T.; ABREU P. S.; RODRIGUES A. C.; BORGES P. R. S.; BATISTA L. R.; CIRILO M. A.; LIMA L. C. O. Physicochemical and microbiological quality of raspberries (Rubus idaeus) treated with diferente doses of gamma radiation. F Sci Techn, v. 33, p. 316-322, 2013. 